\title{
Quality Status of Siak River of Silver Part in Riau Province, Indonesia
}

\author{
Eni Sumiarsih $^{1}$, Muhammad Fauzi ${ }^{2}$, Eko Purwanto ${ }^{3}$, Ika Fitria Hasibuan ${ }^{4}$ \\ Department of Water Resources Management, Faculty of Fisheries and Marine, University of Riau, Indonesia \\ Campus Bina Widya, Km 12, 5 Panam
}

\begin{abstract}
Siak River is one of four major rivers in Riau Province with a depth of 20-30 $\mathrm{m}$, is a water transportation route, a source of raw water for drinking water companies, household needs for the community, wood processing industry, and fishery activities. This study aims to determine the condition of water quality and water quality status in Hulu Sungai Siak. The study was conducted in May 2017, with three observations at 3 stations. Determination of water quality status of Siak River is based on physical and chemical parameters of waters, using STORET method and Class III water quality standard as its comparator. The results showed that the status of Upper Siak River quality can be categorized as medium contamination. At Station I obtained a total score of -22, Station II obtained a total score of -22 and Station III obtained a total score of -20. The overall status of waters upstream of Siak River is classified in medium class (medium) or medium contaminated with score $-11 \mathrm{~s} / \mathrm{d}-30$.
\end{abstract}

Keywords: Water Quality, Storet Method, Siak River, Status of Quality

\section{Preliminary}

Siak River is the deepest river in Indonesia with an average depth of 20-30 m (DPU 2005), but now its depth is only 812 m (BLH Riau Province 2011). This river crossed several districts and cities in the Riau province of Indonesia, including Rokan Hulu regency, Kampar regency, Siak Regency, Bengkalis district and Pekanbaru city, with a river length of approximately $300 \mathrm{~km}$ (BPS Riau 2013). This river plays an important role as water transportation, fishery activities, raw water sources for industry and drinking water companies in Pekanbaru City as well as for bathing and washing for most of the people along the river. The main causes of critical Siak River include domestic waste disposal (60\% of pollutants come from households and industrial wastes) (Ridwan 2014 and DPU 2005). While anthropogenic activity around the Siak River has affected the conditions of the waters of the Siak River until the Siak River is currently experiencing severe polluted conditions.

Water quality is the quality of water that meets the standards and requirements for a particular purpose. Water quality can be known by measuring physics change (Temperature, Strong current and Turbidity), chemistry (pH and DO) and biology (Macroinvertebrate) (Subekti, 2009). Based on the results of water quality measurements in the Siak River reported by the Riau Province Environmental Agency, the quality of the Siak River has been categorized as heavily polluted and reaches dangerous levels. The poor quality of the Siak River has had a negative impact on the communities surrounding the river. Pollutants entering into the waters of the Siak River have also threatened the existence of aquatic ecosystems, the loss of the river's natural habitat, the survival of fish and another aquatic biota, to the decline of fish-specific fish populations in Riau province and has resulted in decreasing catches of fishermen in the area. To know the current status of quality about the waters quality of Upper Siak River, research on the determination of thestatus of waters quality of Siak River of Upper Section.

\section{Research Methods}

The study was conducted in May 2017 in the Upper Siak River, Riau Province (Figure 1). The location of this research is divided into 3 stations, and its 2 stations are located in Bencah Kelubi Village Tapung Raya District Pekanbaru City, Riau, namely: station 1, which there are many fishing activities using fishing rods, nets and traps and station 2 there are many fishery activities using Floating Net Cages (KJA) and oil palm plantations. While station 3 is located in Rumbai district, there is theactivity of port of goods and passenger port, close to rubber factory area (PT Riau Crumb Rubber Factory) and community residence activity.

The tool used in this research is Van Dorn water sampler, Secchi disk, cooling box and Global Positioning System (GPS). Methods of data collection using survey method. Water sampling in the field was conducted at one-week intervals for three weeks. Water sampling is done by using Van Dorn water sampler. Parameters directly observed are brightness using Secchi disk, $\mathrm{pH}$ measured using indicator $\mathrm{pH}$ with litmus paper scale $0-14$, the thermometer to measure water temperature and titration equipment for dissolved oxygen field analysis. Other water quality parameters are BOD5, orthophosphate, turbidity, ammonia, nitrate and oil and fat samples of water stored in acooling box $\left(4{ }^{\circ} \mathrm{C}\right)$ analysed in thelaboratory of Ecology and Waters Environment Management of University of Riau. Water quality analysis refers to APHA (1995) which is analysed in the laboratory of Water Ecology Faculty of Fisheries and Marine Sciences. Furthermore, to determine the status of waters quality of Upper Siak River using STORET method (KEPMEN No.115 / MENLH / 2003), that is by comparing water quality data with water quality standard class III (PP No. 82 theyear 2001). The method of determining the status of water quality is to use the value system of "US-EPA (United State Environmental Protection Agency)" by classifying water quality into four classes (Table 1). 


\section{International Journal of Science and Research (IJSR) \\ ISSN (Online): 2319-7064}

Index Copernicus Value (2016): 79.57 | Impact Factor (2015): 6.391

Table 1: Determination of status of water quality by STORET method

\begin{tabular}{|c|c|c|}
\hline Class & Score & Criteria \\
\hline A & 0 & very good (Meet the Quality Standard) \\
\hline B & -1 to -10 & Good (Lightly Contaminated) \\
\hline C & -11 to -30 & Medium (Medium Medium) \\
\hline D & $\geq-31$ & Poor (Poorly Contaminated) \\
\hline
\end{tabular}

The result of measurement of each water quality parameter if it meets the water quality standard then given score 0 and if the measurement results do not meet the water quality standard then given the score as in Table 2

Table 2: Determination of the value system for water quality status

\begin{tabular}{|l|l|c|c|c|}
\hline \multirow{2}{*}{ Total sample } & \multirow{2}{*}{ Value } & \multicolumn{3}{|c|}{ Parameters } \\
\cline { 3 - 5 } & & Physic & Chemist & Biology \\
\hline \multirow{3}{*}{$<10$} & Maximum & -1 & -2 & -3 \\
\cline { 2 - 5 } & Minimum & -1 & -2 & -3 \\
\cline { 2 - 5 } & Mean & -3 & -6 & -9 \\
\hline
\end{tabular}

\section{Results and Discussion}

\section{Conditions of water quality}

The physical, chemical and biological characteristics of the waters of the Upper Siak River during the study were varied. Based on the measurement of water quality parameters during the research, the average range of water temperature is $30-310 \mathrm{C}$. The maximum value of temperature is at thestation I, this is because the temperature measurement at thestation I am done during the day. The variation of thetemperature value is caused by the difference of measurement time, the weather is quite hot at the time of measurement, as well as the location of the sampling is rather shallow, thus giving effect to the warming of sunlight can reach the bottom of the water. According to Efriyeldi (2005), shallow waters cause the influence of solar heating can reach the bottom of the water. when compared to Water Quality Standard according to PP. 82 The year 2001 class III then the waters upstream of Siak River is still quite natural for the life of water biota.

Results Measurement of water brightness at each observation station ranged from 34.7 to $61.0 \mathrm{~cm}$. while the turbidity measurements ranged from 6.4 to $23.1 \mathrm{NTU}$ and the TSS measurements during the study ranged from 3.0 $4.7 \mathrm{mg} / \mathrm{L}$. According to Effendi (2003) factors that affect the value of brightness are weather conditions, measurement time, turbidity and suspended solids and measurement accuracy. According to Ridwan et all (2016) states that the brightness of water closely related to the penetration of light entering the water column. Meanwhile, Sinambela \& Sipayung (2015) stated that the low brightness is influenced by the particles and sediments that drift away from the erosion of land and rainy season.

The lowest turbidity value is in Station I and the highest is in Station 2. The water level of the waters is inversely proportional to the level of turbidity in water. While the value of turbidity in line with the value of TSS in water. The TSS value during the study ranged from $3.0-4.7 \mathrm{mg} / \mathrm{L}$, the lowest TSS was in Station I and the highest was in Station 2.

\section{Current Speed}

Based on the measurement of current velocity value of waters upstream of Siak River ranged from 0.3 to $0.4 \mathrm{~m} / \mathrm{s}$. The lowest current velocity value is at Station I and the highest is in Stations 2 and 3. The current velocity in this river is very slow, as Harahap (1999) found that water flow rate $0-25 \mathrm{~cm} / \mathrm{s}$ is slow, $25-50 \mathrm{~cm} / \mathrm{s}$ is moderate, water flow rate $50-100 \mathrm{~cm} / \mathrm{s}$ is quite fast, water flow rate $>100 \mathrm{~cm} / \mathrm{s}$ is very fast. The current velocity of the Siak River is very influential on its ability to assimilate and transport contaminants in the waters.

\section{pH (degree of acidity)}

Acidity or acidity $(\mathrm{pH})$ levels include parameters for determining water quality. Based on the research results $\mathrm{pH}$ value during the study has the same value on each station that is 5 (Figure ...). There was no difference in $\mathrm{pH}$ value of each station during the sample measurement. When compared with the quality standard of PP No. 82 on Water Quality Management class III pH value of waters of Siak River is still good. whereas according to Situmorang (2007) that, unpolluted water is at a $\mathrm{pH}$ scale of 6.0-8.0.

\section{Dissolved Oxygen (DO)}

The average measurement of dissolved oxygen content ranged from 3.1 to $4.4 \mathrm{mg} / \mathrm{l}$. The lowest dissolved oxygen values are at Station I and the highest is in Station III. The results of dissolved oxygen measurements influenced human activities in the watershed (DAS) as well as the amount of waste organic waste. The value of dissolved oxygen content in these two stations is not much different. According to Barus (2001), that the oxygen value dissolved in water can fluctuate due to the influence of changes in temperature and photosynthetic activity of plants in waters that produce oxygen. According to Pescod (1973), the dissolved oxygen content that supports the life of aquatic organisms must be greater than $2 \mathrm{mg} / \mathrm{L}$.

\section{Carbon dioxide ( $\mathrm{CO} 2)$}

Based on the measurement of carbon dioxide $(\mathrm{CO} 2)$ in the waters upstream of Siak River, the average concentration of carbon dioxide (CO2) is about $29.16-32.96 \mathrm{mg} / \mathrm{L}$. The concentration of carbon dioxide is in Station I and the lowest is at Station 3. The high concentration of carbon dioxide in the waters of the Siak River is caused by the number of organisms that conduct respiration in the water so much need of carbon dioxide and the high decomposition process of this irrigated organic matter. Boyd (1982) which states that the carbon dioxide content present in the waters is the result of carbon dioxide diffusion from the air and the respiration process of aquatic organisms and also produced by the decomposition process. Asmawi (1986) added that the free carbon dioxide content of water should not be> 12 $\mathrm{mg} / \mathrm{L}$ and should not $<2 \mathrm{mg} / \mathrm{L}$. thus, the carbon dioxide content in the waters of the Upper Siak River is not good for aquatic organisms (Samuel, \& Adiansyah, V., 2016). 


\section{International Journal of Science and Research (IJSR) \\ ISSN (Online): 2319-7064}

Index Copernicus Value (2016): 79.57 | Impact Factor (2015): 6.391

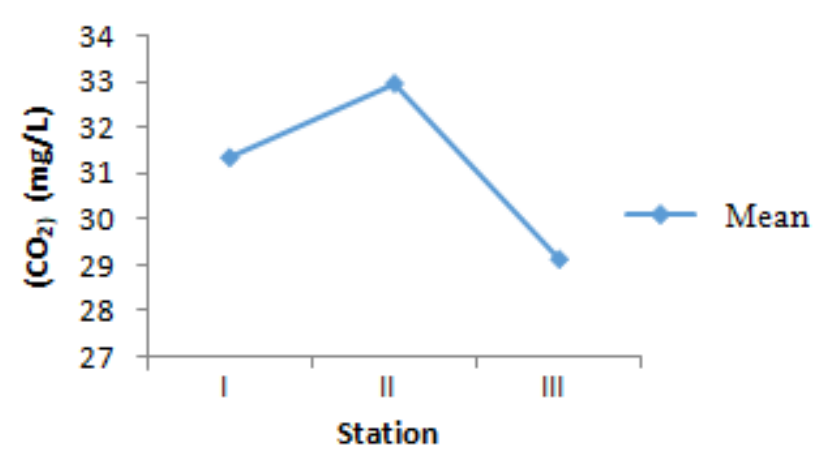

Figure 1: Graph of carbon dioxide values during the study

\section{Biochemical Oxygen Demand (BOD5)}

The average BOD5 measurements obtained in upper waters of the Siak River range from $16.7-38.6 \mathrm{mg} / \mathrm{L}$. The result is above the water quality standard class III category contained in PP. 82 of 2001 stating that, the value of BOD5 should not exceed $6 \mathrm{mg} / \mathrm{L}$.

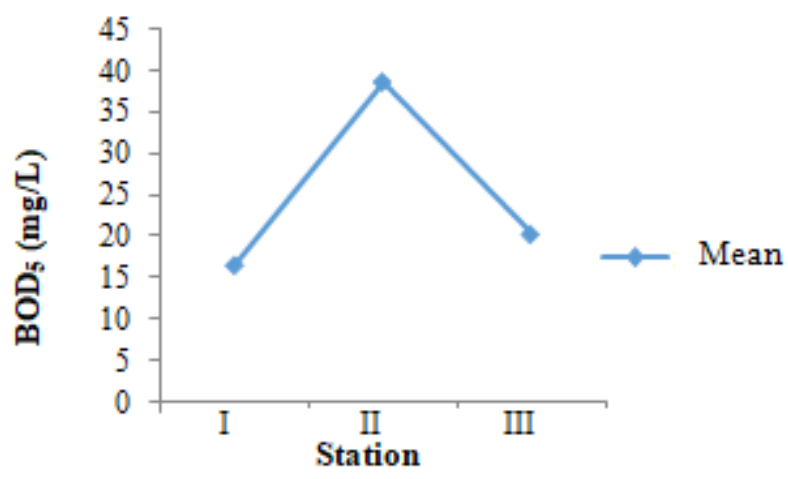

Figure 2: Graph of BOD5 value during the study

Based on that, the waters of Upper River of Siak River have not fulfilled for the cultivation of freshwater fish, farm and water to irrigate the crop. When compared with research conducted Gulo et all (2015) in Belawan River is very much different from the waters of this Siak River, BOD value in Belawan River $\leq 2 \mathrm{mg} / 1$. the condition of Siak River if seen from BOD, this condition is same with thecondition of Tondano River BOD value in range 15,5 - $44 \mathrm{mg} / \mathrm{L}$ (Lensun and Sipriana, 2013). Based on the results of research conducted in Tondano River BOD value in these waters are in the range of 15.5 to $44 \mathrm{mg} / \mathrm{L}$ from domestic waste disposal.

\section{Chemical Oxygen Demand (COD)}

Organic pollutants that can not be broken down by organisms but described with chemicals are measured by Chemical Oxygen Demand (COD). The COD values obtained during the study in Upper Siak River waters ranged from 8.5 to $17.6 \mathrm{mg} / \mathrm{L}$. The lowest COD value is in Station 3 and the highest is in Station 2, when compared with PP. 82 The year 2001 value of COD waters upstream of Siak River still on the boundary of standard water quality class III because no more than $50 \mathrm{mg} / \mathrm{L}$. COD values can be used as a guide to environmental pollution (Mahida, 1984). Boesc et al. (in Rambe, 1999) suggest that high COD values indicate that the region contains many organic substances comprising hydrocarbon components plus small amounts of oxygen, nitrogen, sulphur and phosphorus. Uncollected COD water values are usually less than $20 \mathrm{mg} / \mathrm{l}$, whereas in contaminated waters greater than $200 \mathrm{mg} / 1$ and in industrial waste may reach $600,000 \mathrm{mg} / 1$. overall this indicates that the upstream waters of the Siak River are still able to support the life of aquatic organisms and if viewed from the COD value of these waters has not been contaminated. If the COD value is low then the BOD value will be higher (Amri, 2007).

\section{Nitrate}

Nitrate is the main form of nitrogen in natural waters and is a major nutrient for the growth of plants and algae (Effendi, 2003). The results of nitrate measurements in the waters of the Upper Siak River ranged from 0.556 to $1.295 \mathrm{mg} / \mathrm{L}$. The lowest nitrate value is at Station 3 and the highest at Station I. When viewed from its nitrate content, the waters of the Siak River are classified as having no high fertility. According to Nugroho (2006), the classification of water fertility based on nitrate content of 1.13 to $11.29 \mathrm{mg} / \mathrm{l}$ belongs to waters with high fertility.

\section{Orthophosphate}

Based on orthophosphate measurement results, it is known that the average value of orthophosphate in all measurement stations is $0.243-0.2847 \mathrm{mg} / \mathrm{L}$. This range still meets the phosphate levels in natural waters. According to Boyd (1988) in Zola (2004) natural water phosphate levels rarely exceed $1 \mathrm{mg} / 1$. the lowest value is in Station 3 and the highest is in Station I. Judging from the phosphate content, that is between $0.118-0.15 \mathrm{mg} / \mathrm{l}$ waters of the Siak River classified as water species that have high fertility. This is in accordance with the statement Nugroho (2006) that the classification of water fertility based on the phosphate content of $0.10-0.20 \mathrm{mg} / \mathrm{l}$ pertained waters with high fertility.

\section{Oil and fat}

The mean concentrations of oils and fats during the study ranged from $86700-339700 \mu \mathrm{g} / \mathrm{L}$. The lowest concentration of oil and fats is in Station 3 and the highest is in Station I. Oil and fat concentration in comparison with Government Regulation No. 82 of 2001 class III grade of oil and fat concentration in Upper Siak River has exceeded the standard of quality that should not be more from $1000 \mu \mathrm{g} /$ L.

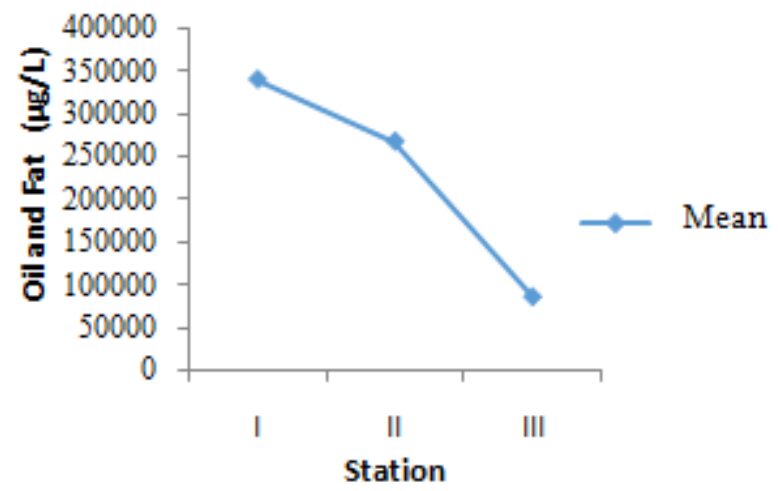

Figure 3: Graph of oil and fat values during the study

The status of the quality of the water of the Upper Siak River. The status of water quality is the level of water quality condition that indicates the condition of apollutant or good condition at a water source within a certain time by

\section{Volume 6 Issue 12, December 2017}

\section{www.ijsr.net}




\section{International Journal of Science and Research (IJSR) \\ ISSN (Online): 2319-7064}

Index Copernicus Value (2016): 79.57 | Impact Factor (2015): 6.391

comparing with the water quality standard specified (Kepmen LH 2003). Determination of water quality status of Upper Waters of Siak River other than by using descriptive analysis, water quality also analysed by using STORET method. The use of STORET method is intended to know well the poor quality of water in a body other water for a particular water designation. In addition to this method can also be known what parameters that have exceeded or did not meet the quality standards that have been determined.
The value of STORET when compared to the Class III Class I station I obtained a total score of -22 , on Station II, obtained total score -22 and Station III obtained a total score of -20 . Based on the STORET method, it can be said that the overall quality status of upper waters of the Siak River is classified as medium (medium) or medium-contaminated with a score of - $11 \mathrm{~s} / \mathrm{d}-30$ (Figure 4).

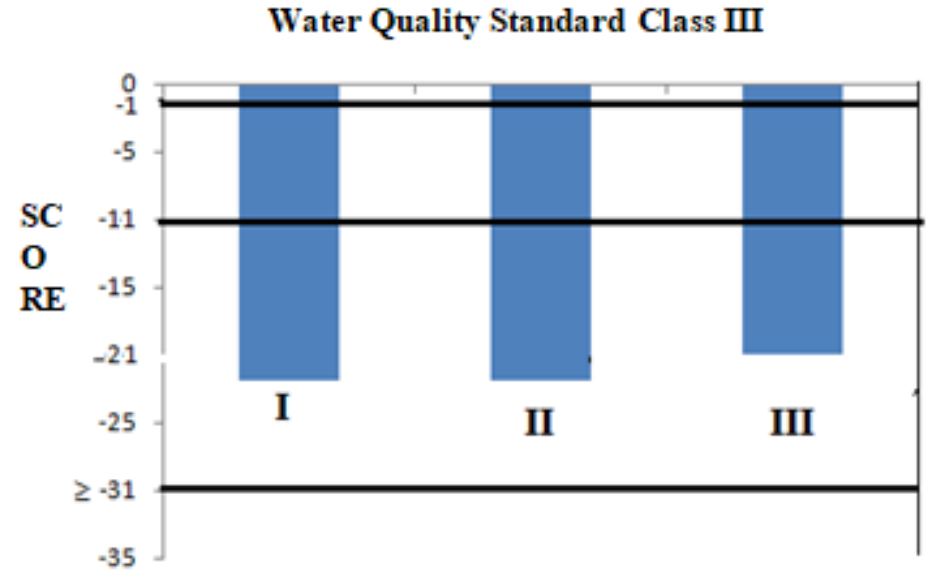

Meet the water quality standards

Polluted lightly

Polluted mediu

Figure 4: STORET index value of each station in the waters upstream of Siak River

Contaminants' contribution to each station in the research location is not much different because of the activities around the same station. Some parameters measured have reached the limit of water quality standards based on Government Regulation No. 82 of 2001 on Water Quality Management and Class III Pollution Control. The parameters that have exceeded the quality standard are BOD5, oil and fats while carbon dioxide also exceeds the maximum value limit for fresh water that should not exceed $12 \mathrm{mg} / \mathrm{L}$.

Upstream waters of the Siak River are classified as medium polluted and the watershed quality parameters of BOD5 are very high because of the activity around the Upper Siak River that affects the high concentration of BOD5 in these waters, the activity that triggers the high concentration of organic materials in this waters are suspected the influence of industrial activity and domestic waste and plantations that exist around the river. According to lensun and sipriana (2013) community activities in the form of domestic waste disposal, fish feed and industry around the waters of the river will affect the BOD in the water.

The watershed BOD is also a determinant of the digestive level from upstream to downstream, in accordance with the opinion of Salmin (2005). BOD parameters are generally used to determine the level of wastewater pollution. Determination of BOD is very important to trace the flow of pollution from the upstream to the estuary (Engineering, 2012). The high concentration of carbon dioxide in this water is also not good for the life of aquatic organisms because it is more than $12 \mathrm{mg} / 1$. the concentration of oil and fat also exceeded the standard quality threshold according to PP 82 of 2001 which should not be more than $1000 \mu \mathrm{g} / \mathrm{L}$. The high concentration of oil and fats in the waters of Sungai Siak River is thought to come from industrial waste disposal in the area around the river (Trisnawati, A., \& Masduqi, A., 2013). If the waters are already contaminated by oils and fats this will affect the life of aquatic organisms (Agustiningsih, D., Sasongko, S. B., \& Sudarno, 2012).

For that it needs to be done further management of the upstream waters of the Siak River that has been categorized as contaminated, if not managed feared will have an impact on the life of aquatic organisms, especially fish that exist in this waters. It will also have an impact on the worsening ecosystem (Putri, N. A. D., 2011). Given this river provides many special benefits for people who use this river as a source of livelihood as fishermen who catch fish from upstream to downstream of this Siak river.

\section{Conclusion}

Based on the calculation of STORET method of Upper River Siak has reached medium level. This pollution is caused by existing activities around the river, agricultural erosion, plantation and industrial activities. For BOD5 parameters, the oils and fats and carbon dioxide have exceeded the specified quality standard. Water quality monitoring of the Siak River needs to be carried out periodically and socialized to the community, it is necessary to restrict land use activities in the vicinity of good River utilization for agriculture, settlement and industry.

\section{Acknowledgments}

The researcher would like to thank LPPM University of Riau, which has provided opportunity and fund to conduct research on this Siak River. Next, we thank the other research team members who helped during this research.

\section{Volume 6 Issue 12, December 2017}




\section{International Journal of Science and Research (IJSR) \\ ISSN (Online): 2319-7064}

Index Copernicus Value (2016): 79.57 | Impact Factor (2015): 6.391

\section{References}

[1] Agustiningsih, D., Sasongko, S. B., \& Sudarno. (2012). Analysis of water quality and control strategy of river water pollution control district Blukar. Journal of Precipitation, 9 (2), 64-71. Retrieved from https://www.mysciencework.com/publication/show/14 434915531f78347fbb1bc717df10ea (English)

[2] Asmawi, S., 1986. Fish Cultivation in Keramba. Gramedia. Jakarta. 82 things (Indonesia)

[3] Barus, T. A. 2001. Introduction to Limnology Studies on Mainland Water Ecosystems. USU Press. University of Sumatera Utara Medan (Indonesia)

[4] Lensun, M and Sipriana T. 2013. Tondano River Water Pollution Level in Ternate Baru Urban Manado City. 1 (2): 43-48 (Indonesia)

[5] Mahida, U.N. 1984. Water Pollution and Industrial Waste Utilization. Translated by G.A. Ticoalu. Rajawali, Jakarta (Indonesia)

[6] Makmur, Rachmansyah, \& Fahrur, M. (2011). The Relationship Between Water Quality and Plankton in Ponds Kabupaten Tanjung Jabung Barat Jambi Province. Proceedings of Aquaculture Technology Innovation Forum 2011, 961-968 (Indonesia)

[7] Nugroho, A. 2006. Bio indicator Water Quality. Trisakti University. Jakarta, Indonesia)

[8] Pescod MB. 1973. Investigation of Rational Effluent and Stream Standard for Tropical Countries. Bangkok: Environmental Engineering Division Asian InstituteTechnology

[9] Princess, N. A. D. (2011). Government Policy in Control of Pollution of River Water SIAK. Journal of Political Science and Government Science, 1 (1), 6879 (Indonesia)

[10] Ridwan M, Rizal F, Ishma F, Danang AP. 2016. Macrozoobenthos Community Structure in the Four Estuary Rivers of Pulau Dua Nature Reserve, Serang, Banten. Al-Kauniyah Journal of Biology. 9 (1), 57-65 (Indonesia)

[11] Salmin. 2005. Dissolved Oxygen (DO) And Biological Oxygen Needs (BOD) As One of The Indicators For Determining Water Quality. Oceana, Volume XXX, Number 3, 2005: 21-26 (Indonesia)

[12] Samuel, \& Adiansyah, V. (2016). WATER QUALITY, TROPHIC STATUS AND POTENCY OF LAND FISH PRODUCTION ABOVE, WEST SUMATERA. J. Lit. Fishing. Ind., 22 (2), 83-94 (Indonesia)

[13] Sinambela M, Sipayung M. 2015. Macrozoobenthos with physical and chemical parameters in Babura River waters of Deli Serdang Regency. Journal of Bioscience. 1 (2), 44-50 (Indonesia)

[14] Technique. (2012). Control over the conversion of paddy fields into oil palm plantations in Siak-Riau regency. Urban and Regional Planning Techniques, 1 (1), 1-3. Retrieved from http://digilib.its.ac.id/public/ITS-paper-268023607100027-Paper.pdf (English)

[15] Trisnawati, A., \& Masduqi, A. (2013). Quality Analysis and Strategy of Pollution Control Surabaya River. Purification Journal, 14 (2), 90-98 (Indonesia)

[16] WE Doods. 2002. Freshwater Ecology: Concepts and Environmental Applications. San Diego: Academic Press
[17] Zola, E. 2004. Macrozoobenthos as Bio-Sensor River Pollution Around Water Disposal Site of Liquid Wastes RSUD Serang. Essay. Faculty of Math and Science. The University of Lampung. Bandar Lampung. (not published) (English)

Volume 6 Issue 12, December 2017

www.ijsr.net

Licensed Under Creative Commons Attribution CC BY 